Araştırma Makalesi / Research Article

\author{
Geliş tarihi / Received: 19-02-2021 \\ Kabul tarihi / Accepted: 17-03-2021
}

Atıf İçin: Tekin F, Eryiğit T, Tunçtürk M, 2021. Farklı Azot ve Fosfor Dozlarının Diyarbakır Ekolojik Koşullarında Kişniş (Coriandrum sativum var. microcarpum DC.) Bitkisinin Verim ve Bazı Verim Unsurları Üzerine Etkisi. Iğdır Üniversitesi Fen Bilimleri Enstitüsü Dergisi, 11(3): 2389-2399.

To Cite: Tekin F, Eryiğit T, Tunçtürk M, 2021. Effect of Different Nitrogen and Phosphorus Doses on Yield and Some Yield Components of Coriander Plant (Coriandrum sativum var. microcarpum DC.) in Diyarbakir Ecological Conditions. Journal of the Institute of Science and Technology, 11(3): 2389-2399.

\title{
Farklı Azot ve Fosfor Dozlarının Diyarbakır Ekolojik Koşullarında Kişniş (Coriandrum sativum var. microcarpum DC.) Bitkisinin Verim ve Bazı Verim Unsurları Üzerine Etkisi
}

\author{
Fethullah TEKİN ${ }^{1}$, Tamer ERYİ̈̆̇̇² ${ }^{2 *}$, Murat TUNÇTÜRK ${ }^{3}$
}

ÖZET: Bu çalışmada, Diyarbakır ekolojik koşullarında kişniş bitkisinde verim ve bazı verim unsurları üzerine azot ve fosfor dozlarının etkisinin belirlenmesi amaçlanmıştır. Coriandrum sativum var. microcarpum DC. eko tipinin materyal olarak kullanıldığı çalışma, tesadüf bloklarında bölünmüş parseller deneme desenine göre dört tekerrürlü olarak yürütülmüştür. Çalışmada, dört azot dozu (0, 3, 6 ve $\left.9 \mathrm{~kg} \mathrm{da}^{-1}\right)$ ve dört fosfor dozu (0, 2, 4 ve $\left.6 \mathrm{~kg} \mathrm{da}^{-1}\right)$ deneme faktörü olarak kullanılmıştır. Araştırmada, bitki boyu, toplam dal sayısı, bin dane ağırlığ 1 , tane verimi, biyolojik verim ve hasat indeksi gibi özellikler incelenmiştir. Araştırmada sonucunda, uygulanan farklı azot ve fosfor gübre dozlarından elde edilen veriler birlikte değerlendirildiğinde; bitki boyunun (62.5 - $75.0 \mathrm{~cm})$, toplam dal sayısının (36.8 - 56.2 adet/bitki), bin dane ağırlığının (4.9 $5.4 \mathrm{~g}$ ), tohum veriminin $\left(149.5\right.$ - $\left.184.5 \mathrm{~kg} \mathrm{da}^{-1}\right)$, biyolojik verimin $\left(391.3\right.$ - $\left.591.1 \mathrm{~kg} \mathrm{da}^{-1}\right)$ ve hasat indeksinin $(\% 32.0$ - 41.0$)$ aralıklarında değiştiği tespit edilmiş ve en yüksek tohum veriminin $\left(184.5 \mathrm{~kg} \mathrm{da}^{-1}\right)$ dekara $9 \mathrm{~kg}$ azot ve $4 \mathrm{~kg}$ fosfor gübre kombinasyonundan alındığı saptanmıştır. Sonuç olarak Diyarbakır ekolojik koşullarında kişniş için en uygun azot ve fosfor gübre kombinasyonun dekara $6 \mathrm{~kg}$ azot ve $4 \mathrm{~kg}$ olduğu tespit edilmiştir.

Anahtar Kelimeler: Kişniş (Coriandrum sativum L.), azot dozu, fosfor dozu, verim

\section{Effect of Different Nitrogen and Phosphorus Doses on Yield and Some Yield Components of Coriander Plant (Coriandrum sativum var. microcarpum DC.) in Diyarbakir Ecological Conditions}

\begin{abstract}
In this study, it was aimed to determine the effect of nitrogen and phosphorus doses on yield and some yield elements in coriander plant in Diyarbakir ecological conditions. The study, in which the echo type Coriandrum sativum var. microcarpum DC. was used as a material, was conducted in four repetitions according to the trial pattern of split plots in

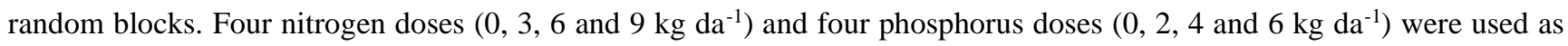
trial factors in the trial. In the study, some yield characteristics such as plant height, total number of branches, thousand seed weight, biological yield, seed yield and harvest index were examined. As a result of the research, when the data obtained from the different nitrogen and phosphorus fertilizer doses applied are evaluated together; plant height $(62.5-75.0 \mathrm{~cm})$, the total number of branches (36.8 - 56.2 pieces/plant), thousand-seed weight (4.9 - $5.4 \mathrm{~g})$, seed yield (149.5 - $\left.184.5 \mathrm{~kg} \mathrm{da}{ }^{-1}\right)$, biological yield $\left.(391.3-591.1 \mathrm{~kg}) \mathrm{da}^{-1}\right)$ and harvest index $(32.0 \%-41.0 \%)$ were found to be varied in the intervals. It was determined that the highest seed yield $\left(184.5 \mathrm{~kg} \mathrm{da}^{-1}\right)$ was obtained from the combination of $9 \mathrm{~kg}$ nitrogen and $4 \mathrm{~kg}$ phosphorus fertilizer per decare. As a result, it was determined that the most suitable nitrogen and phosphorus fertilizer combination for coriander in Diyarbakır ecological conditions is $6 \mathrm{~kg}$ nitrogen and $4 \mathrm{~kg}$ per decare.
\end{abstract}

Keywords: Coriander (Coriandrum sativum L.), nitrogen dose, phosphorus dose, yield

${ }^{1}$ Fethullah TEKİN (Orcid ID: 0000-0003-3710-1705), GAP Uluslararası Tarımsal Araştırma ve Eğitim Merkezi Müdürlüğü, Diyarbakır, Türkiye

${ }^{2}$ Tamer ERYİĞİT (Orcid ID: 0000-0001-5069-8206), Van Yüzüncü Yıl Üniversitesi, Gevaş Meslek Yüksekokulu, Bitkisel ve Hayvansal Üretim Bölümü, Van, Türkiye

${ }^{3}$ Murat TUNÇTÜRK (Orcid ID: 0000-0002-7995-0599), Van Yüzüncü Y1l Üniversitesi, Ziraat Fakültesi, Tarla Bitkileri Bölümü, Van, Türkiye

*Sorumlu Yazar/Corresponding Author: Tamer ERYİĞİT, e-mail: tamyigit@ hotmail.com 


\section{GíRiș}

Kişniş Umbelliferae (Şemsiyegiller) familyasına ait Coriandrum cinsinden tek yıllık otsu bir baharat bitkisidir (Davis 1984). Üç bin yıldan beri Mısır, Çin ve Hindistan'da baharat ve tıbbi amaçla kullanılmaktadır. Coriandrum cinsine ait iki tür (C. tordylium ve $C$. sativum L.) tespit edilmiştir. Bu türlerden tarımı çok eskilere dayanan sativum türünün üretimi yapılmaktadır. Dünyada yaygın olarak tarımı yapılan varyete ise macrocarpum'dur. Türkiye'de en çok C. sativum var. Macrocarpum olmak üzere $C$. sativum var. microcarpum sativum türüne ait iki alt varyetenin tarımı yapılmaktadır (Davis 1984). Macrocarpum varyetesinin bin dane ağırlığ $10 \mathrm{~g}$ üzerinde ve meyve çapı da $3 \mathrm{~mm}$ üzerindedir. Türkiye'de Mardin, dünyada ise Hindistan tipi kişniş olarak da bilinir. Microcarpum varyetesinin bin dane ağırlığı ise 10 g'ın altında ve meyve çapı da 3 mm'nin altındadır. Türkiye'de Denizli veya Erzurum, dünyada ise Rus tipi kişniş olarak da bilinir (Diederichsen 1996; Tunçtürk 2011). Anadolu, Kafkasya, Asya ve Avrupa'da yabani olarak yetişmektedir. Doğal olarak step araziler, çayırlıklar ve çorak yerlerde yetişir.

Kişniş geniş kullanım olanı olan bir bitkidir. Genelde meyvesinden (tohum) faydalanılır. Fakat son yıllarda kişnişin ağır metalleri vücuttan uzaklaştırdığı yöndeki etkisi ortaya çıktıkça taze olarak tüketimi de gittikçe artmaktadır. Taze aksamı bazı ülkelerde Çin Maydanozu olarak da bilinir (Kırıcı ve ark. 1997). İngiltere'de ise pazar ve manavlarda farklı bir maydanoz çeşidi olarak satılmaktadır. Erzurum yöresinde taze aksamı, taze aksamının kurutulmuş hali ve taze aksamında yapılan salamurası aş otu olarak kullanılmaktadır (Tunçtürk ve Sciences 2006).

Kişniş meyvesi önemli derecede protein, vitamin, karbonhidrat, sabit yağ ve uçucu yağ içermektedir. Bundan dolayı da baharat, gıda, ilaç, kozmetik ve bitkisel halk ilacı olarak tüketilmektedir. Kişniş meyvesi \%1.5 düzeyinde uçucu yağı içerir. Uçucu yağında yüksek oranda güzel kokuya sahip linalool (\%94-98) (Özel ve ark. 2009) ve sabit yağında antimikrobiyal etkiye sahip petroselinik asit (\%60-70) bulunduğundan dolayı kozmetik ve ilaç sanayisi için değerli bir ham maddedir (Kaya ve ark. 2000). Uçucu yağı kan zehirlemelerinde (sepsis) antioksidan olarak kullanılmaktadır. Meyvesinde \%30 oranında ham protein ve önemli oranda $A$ ve $C$ vitaminleri içermesinden dolayı birçok gıda ve içecek yapımında kullanılmaktadır (Beyzi ve Gürbüz 2010). Damıtılmış posasında \%10-17 protein ve \%11 ile 20 arasında ham yağ içerdiği için özellikle süt sığırlarında değerli bir hayvan yemidir. Halk arasında kişnişin taze aksamı, tanesi ve uçucu yağı ağır metalleri vücuttan uzaklaştırıcı, iştah açıcı, hazmı kolaylaştırıcı, barsak gazlarını giderici, teskin edici, ağrı kesici, kuvvet verici, parazit düşürücü, idrar söktürücü, baş dönmelerinde, tansiyon düşürücü ve antibakteriyel amaçlı olarak kullanılırken (Beyzi ve Gürbüz 2010), kurutulmuş meyvesi ve/veya tohumu öğütülerek baharat olarak kullanılmaktadır (Saya ve ark. 2001).

Kişnişte tane verimi değişen çevre koşullarına ve yetiştirme tekniklerine bağlı olarak 50 ile 200 $\mathrm{kg} / \mathrm{da}$ arasında değişebilmektedir (Baydar 2005). Verimlilik; genetik yapı, kültürel işlemler ve çevrenin ortaya koyduğu bir faktördür.

Bu çalışmada, Diyarbakır ekolojik koşullarında yetiştirilebilecek kişniş bitkisinde, farklı azot ve fosfor dozlarının verim ve bazı verim unsurları üzerine etkilerinin belirlenmesi amaçlanmıştır.

\section{MATERYAL VE YÖNTEM}

\section{Bitki Materyali}

Denemede materyal olarak sativum türüne ait Coriandrum sativum var. microcarpum varyetelerinden olan Denizli ekotipi kullanılmıştır. 


\section{Deneme Yerinin İklim Özellikleri}

Deneme yeri Dicle Nehri kenarında, taban arazide olup, denizden yüksekliği 609 metre dolayında ve 3756'29.36"N enlem ile 40¹5'16.07"E boylamında yer almaktadır. Güneydoğu Anadolu iklim bölgesine dâhil olup, yazları sıcak ve kurak, kışları ise nispeten soğuk ve yağışlı geçmektedir. Bu araştırmada denemenin yürütüldüğ̈̈ 2015, 2016, 2017 ve uzun y1llara (UY:1981-2017) ait aylık ortalama sıcaklık, toplam yağış ve nispi nem değerleri Şekil 1'de verilmiştir. 2015 ve 2016 yıllarında aylık ortalama sıcaklık değerlerinin uzun yıllara göre düşük, 2017'nin ise daha yüksek olduğu tespit edilmiştir. 2015 ve 2017 yıllarının Mart ve Nisan ayları hariç uzun yıllar ortalamasının oldukça altında aylık yağış değerlerine sahip olduğu saptanmıştır. 2017 yılının Ocak ve Şubat ayları hariç tutulduğun her üç yılda da nispi nem miktarının uzun yıllar ortalamasına kısmen paralel gittiği, fakat Mart ve Nisan aylarında daha yüksek olduğu tespit edilmiştir (Şekil 1).

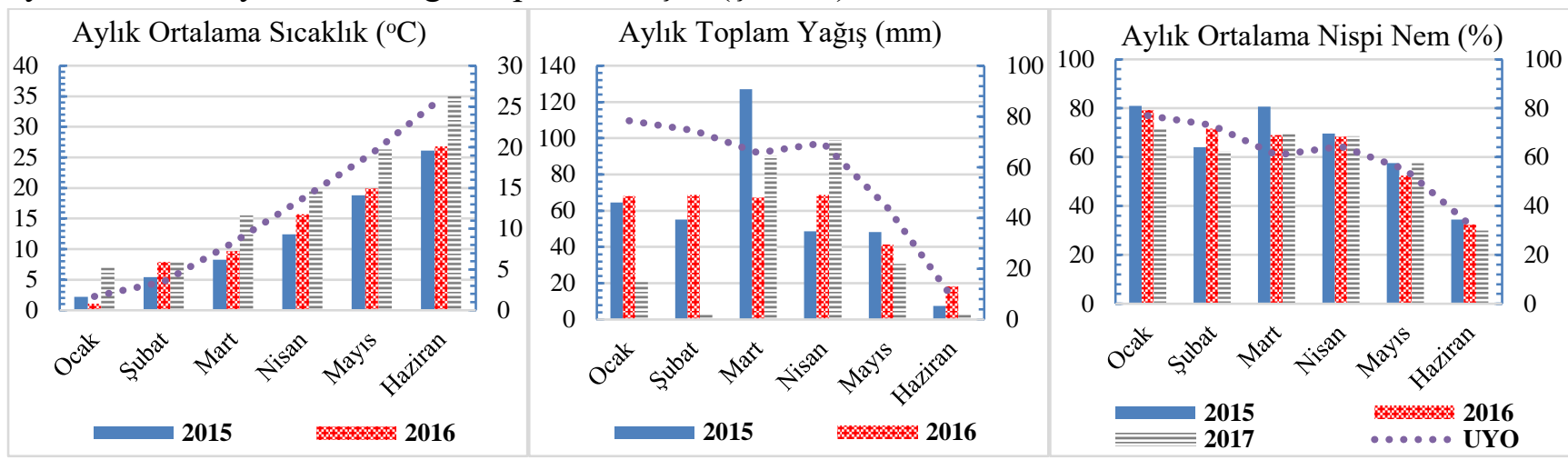

Şekil 1. Denemenin yürütüldüğ̈̈ 2015, 2016, 2017 yılları ve UYO (1981-2017) ortalamalarına ait iklim verileri

\section{Deneme Yerinin Toprak Özellikleri}

Deneme yerinden alınan toprak numunesinin yapılan analizinde aşağıdaki sonuçlar elde edilmiştir. Suya doyma (\%73.18), tuzsuz (\%0.03), bazik ( $\mathrm{pH}: 8.12)$, killi bünyeli, nem (\%32.67), porozite $(\% 47.88)$, kireç $\left(\% 8.02\left(\mathrm{CaC0}_{3}\right)\right.$, fosfor $\left(1.35 \mathrm{~kg} \mathrm{da}^{-1}\right)$, potasyum $\left(92.27 \mathrm{~K}_{2} 0\right)$, organik madde $(\% 0.93)$, tarla kapasitesi (\%41.63), solma noktası (\%18.38), hacim ağırlığı $\left(1.56 \mathrm{~g} \mathrm{~cm}^{-3}\right)$, özgül ağırlığı $(2.83 \mathrm{~g}$ $\mathrm{cm}^{-3}$ ) ve katyon değişim kapasitesi (KDK 25.00 me $100 \mathrm{~g}^{-1}$ )' dir (Tablo 1).

Tablo 1. Deneme yeri topraklarının bazı fiziksel ve kimyasal özellikleri

\begin{tabular}{|c|c|c|c|c|c|c|c|c|}
\hline $\begin{array}{c}\text { Toprağın } \\
\text { bünyesi }\end{array}$ & $\begin{array}{c}\text { Su ile } \\
\text { Doyma } \\
(\%)\end{array}$ & $\begin{array}{c}\text { Tuz } \\
\text { İçeriği } \\
(\%)\end{array}$ & pH & Kum (\%) & Kil (\%) & Silt (\%) & $\operatorname{Nem}(\%)$ & Porozite (\%) \\
\hline Killi & 73.18 & 0.03 & 8.12 & 27.12 & 54.10 & 18.75 & 32.67 & 47.88 \\
\hline $\begin{array}{c}\mathrm{CaCO}_{3} \\
(\%)\end{array}$ & $\begin{array}{c}\mathrm{P}_{2} \mathrm{O}_{5} \\
\left(\mathrm{~kg} \mathrm{da}^{-1}\right)\end{array}$ & $\begin{array}{c}\mathrm{K}_{2} \mathrm{O} \\
\left(\mathrm{kg} \mathrm{da}^{-1}\right)\end{array}$ & $\begin{array}{c}\text { Organik } \\
\text { madde }(\%)\end{array}$ & $\begin{array}{c}\text { Tarla } \\
\text { kapasitesi } \\
(\%)\end{array}$ & $\begin{array}{c}\text { Solma } \\
\text { noktası } \\
(\%)\end{array}$ & $\begin{array}{l}\text { Hacim } \\
\text { ağırlığı } \\
\left(\mathrm{g} \mathrm{cm}^{-3}\right)\end{array}$ & $\begin{array}{c}\text { Özgül } \\
\text { ă̆ırlığı } \\
\left(\mathbf{g ~ c m}^{-3}\right)\end{array}$ & $\begin{array}{c}\text { KDK } \\
\left(\mathrm{me}^{100 \mathrm{~g}^{-1}}\right)\end{array}$ \\
\hline 8.02 & 1.35 & 92.27 & 0.93 & 41.63 & 18.38 & 1.52 & 2.83 & 25.00 \\
\hline
\end{tabular}

\section{Yöntem}

GAP Uluslararası Tarımsal Araştırma ve Eğitim Merkezi Müdürlüğü’ndeki deneme alanında tarla koşullarında kurulan bu çalışma, tesadüf bloklarında bölünmüş parseller deneme desenine göre dört tekrarlamalı olarak önceki yıllarda yapılan çalışmaların bir devamı niteliğinde 2015 - 2017 yıllarında yeniden güncellenerek değerlendirilmiştir. Denemede, alt parsel büyüklükleri [3 $\mathrm{m}$ (sıra uzunluğu) x 5 (sıra say1s1) x $0.45 \mathrm{~m}$ (sıra arasi mesafe $(3 \times 5 \times 0.45)=] 6.75 \mathrm{~m}^{2}$ 'dir. Her alt ve ana parseller arasinda 
$2.5 \mathrm{~m}$ yol birakılmıştır. Denemede, azot dozları ana parsellere $0,3,6$ ve $9 \mathrm{~kg} \mathrm{da}^{-1}$ gelecek şekilde \% 21 'lik amonyum sülfat ve fosfor dozları ise alt parsellerde $0,2,4$ ve $6 \mathrm{~kg} \mathrm{da}^{-1}$ olacak şekilde $\% 46$ 'lık triple süper fosfat ticari gübresi kullanılmıştır. Fosforun tamamı azotun yarısı ekimle birlikte, azotun geri kalan yarısı da çiçeklenmeden önce verilmiştir.

Deneme alanı sonbaharda derin olarak sürülmüş ve ekimden önce toprak tavını kaybetmeden kültivatör ile ikileme yapılmıştır. Arkasından kesekleri kırmak ve toprağı düzeltmek için diskaro ve merdane geçirilmiştir. Deneme sıralar halinde çepinle açılan çizilere tohumlar 2-3 cm derinliğe düşecek şekilde her üç deneme yılında da Mart ayının ilk haftasında elle ekilmiştir. Denemede, bitki köklerinin hava alması ve yabancı ot kontrolü için birincisi bitkiler çıkış yaptıktan sonra, ikincisi ise bitkiler 5-10 cm boylanınca iki kez çapalama yapılmıştır. Deneme yılları kurak geçtiği için ihtiyaç duyuldukça sulama yapılmıştır.

Her bir deneme yılında her alt parselin kenarlarından birer sıra ve uç kısımlarından 0.5 m kenar tesiri bırakıldıktan sonra elle hasat edilmiştir. Hasat edilen bitkiler açık havada kurutulduktan sonra biyolojik verimleri hesaplanmıştır. Kurutulan bitkiler sopa ile ezilerek harmanlanmıştır. Kaba saplar elle üsten ayıklanmıştır. Altta kalan harman önce eleklerden, daha sonrada savurma makinesinden geçirilerek tane ve sap birbirinden ayıklanmıştır.

Araştırmada, bitki boyu (cm), toplam dal sayısı (adet/bitki), bin tane ağırlığı $(\mathrm{g})$, biyolojik verim $\left(\mathrm{kg} \mathrm{da}^{-1}\right)$, tane verimi $\left(\mathrm{kg} \mathrm{da}^{-1}\right)$ ve hasat indeksi (=TV/BV)*100) gibi özellikler incelenmiştir.

\section{Veri Analizleri}

Araştırma sonunda elde edilen verilerin SPSS v 23.0 paket programı ile varyans analizi yapılmış ve saptanan ortalamalar, LSD çoklu karşılaştırma testine tabi tutularak gruplandırılmıştır. İncelenen özelliklerin birbiriyle ilişkilerini saptamak için de korelasyon testi uygulanmıştır.

\section{BULGULAR VE TARTIŞMALAR}

Diyarbakır ekolojik koşullarında kişniş için uygun azot ve fosfor dozlarının belirlenmesine yönelik yürütülen denemenin, bitki boyu, toplam dal sayısı, bin tane ağırlığı, biyolojik verim, tane verimi ve hasat indeksi gibi özellikler ve bu özellikler arasındaki korelasyona ilişkin üç yetiştirme sezonuna ait ortalama veriler sırasıyla aşağıdaki Tablo 2 - 3'te verilmiştir.

\section{Bitki Boyu}

Tablo 2 incelendiğinde, kişnişte bitki boyu üzerine farklı azot ve fosfor dozlarının etkilerinin faktör olarak uygulandığı çalışmada, bitki boyu açısından yıllar arasında meydana gelen farkın istatistiksel olarak çok önemli (\%1) olduğu ve en yüksek bitki boyu ortalama değerinin $(79.6$ ve $81.33 \mathrm{~cm})$ birinci ve üçüncü deneme yıllarında ölçüldüğü saptanmıştır.

Azot dozlarının bitki boyuna etkisi istatistiksel olarak önemli (\%5) olup, en yüksek bitki boyu ortalama değerlerinin $\left(70.2,71.0\right.$ ve 72.0) 0,3 ve $6 \mathrm{~kg} \mathrm{da}^{-1}$ azot dozlarından ve en düşük bitki boyu değerinin (66.6 cm) ise $9 \mathrm{~kg} \mathrm{da}^{-1}$ azot dozu uygulanmasında elde edilmiştir (Tablo 2). Benzer konuda yapılan çalışmalarda, azot dozunun artışına bağlı olarak bitki boyunun da arttı̆g 1 bildirilmektedir (Erdoğdu ve Esendal 2018; Tunçtürk ve Tunçtürk 2008). (Moosavi ve ark. 2015) en yüksek bitki boyunu $8 \mathrm{~kg} \mathrm{da}^{-1}$ azot dozu uygulamasından elde ettiğini rapor etmişlerdir. 
Tablo 2. Kişnişte farklı azot ve fosfor dozları uygulamaları ile değişen bitki boyu, toplam dal sayısı ve bin dane ağırlığı özelliklerine ilişkin, üç yetiştirme sezonuna ait ortalama değerler, oluşturulan gruplar ve LSD değerleri

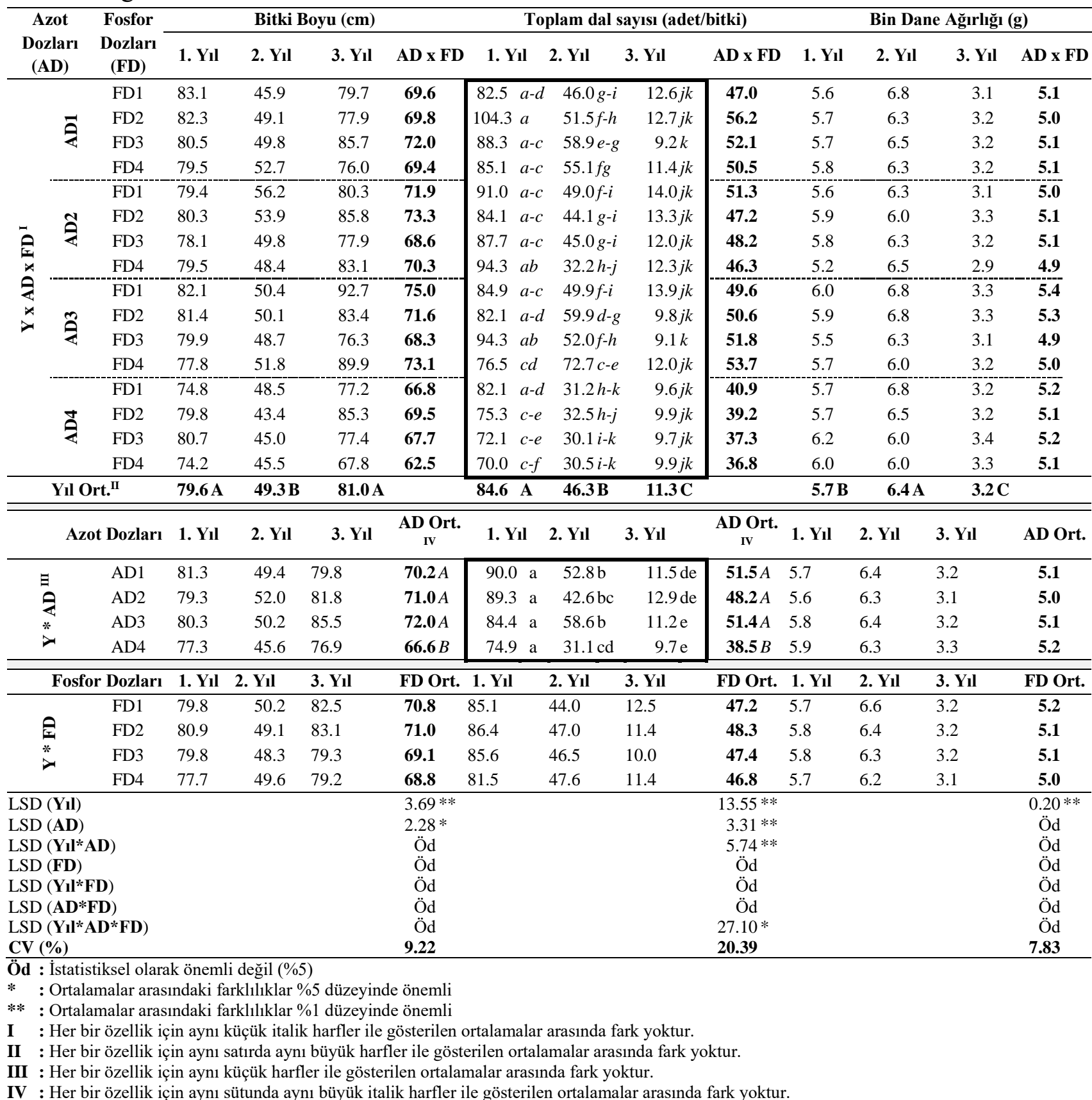

Denemede, farklı fosfor dozlarına ait bitki boyu ortalama değerleri arasında meydana gelen farklılığın istatistiki olarak önemli (\%5) olmadığı ve bitki boyu ortalama değerlerinin 68.8 ile $71.0 \mathrm{~cm}$ arasında değiştiği görülmüştür (Tablo 2). Özyazici (2020) tarafından yürütülen bir çalışmada ise uygulanan fosfor dozlarının bitki boyu üzerinde etkili olduğu ve artan fosfor dozlarının bitki boyu ortalama değerini $9 \mathrm{~kg} \mathrm{da}^{-1}$ fosfor dozuna kadar olumlu etki yaptığı fakat, daha yüksek dozlarda bitki boyunda önemli düşüşlerin yaşandığını bildirmiştir. Denemeler arasındaki bu farklılığın denemelerin yürütüldüğü farklı fosfor içerikli toprak yapısından kaynaklandığı düşünülmektedir.

\section{Toplam Dal Sayısı}

Farklı azot ve fosfor dozları uygulamaları sonucunda elde edilen toplam dal sayısı ortalama değerleri açısından yıllar arasında istatistiksel çok önemli (\%1) farklılıklar meydana gelmiş ve en yüksek 
toplam dal sayısı ortalama değerinin 84.6 adet/bitki ile denemenin birinci yılından, en düşük ise denemenin üçüncü yılında 11.3 adet/bitki olarak tespit edildiği saptanmıştır.

Tablo 2 incelendiğinde, farklı azot dozu uygulamaları sonucu elde edilen toplam dal sayısı ortalama değerleri arasında istatistiki olarak çok önemli (\%1) farklılıkların meydana geldiği ve en yüksek toplam dal sayısı değerinin ilk üç dozdan sırasıyla 51.5, 48.2 ve 51.4 adet/bitki, en düşük ise dördüncü azot dozundan 38.5 adet/bitki olarak alındığı tespit edilmiştir. Üçüncü dozdan sonra uygulanan azot dozunun bitkide toplam dal sayısını önemli ölçüde düşürdüğü tespit edilmiştir. Javiya ve ark. (2017) da yaptıkları çalışmada, azot dozunun $6 \mathrm{~kg} \mathrm{da}^{-1}$ azot dozu uygulamasına kadar bitkide toplam dal sayısı üzerine olumlu etki yaptığını ve daha ada artan dozlarda düşüşlerin yaşandığını rapor etmişlerdir.

Denemede, farklı fosfor dozlarının bitkide toplam dal sayısı üzerine olan etkilerinin istatistiki olarak önemli (\%5) olmadığı ve bitkide toplam dal sayısının 46.8 ile 48.3 adet/bitki arasında değiştiği belirlenmiştir. Bu çalışmanın aksine Javiya ve ark. (2017) ve Özyazici (2020) artan fosfor dozlarının bitkide toplam dal sayısı üzerine olumlu etki yaptığını belirtmişlerdir.

Denemede, azot dozlarının yıllar itibariyle bitkide toplam dal sayısı üzerine etkilerinin farklı olduğu ve bu farklılığın istatistiksel olarak çok önemli (\%1) olduğu saptanmıştır. En yüksek toplam dal sayısı ortalama değerlerinin denemenin birinci yılında istatistiki olarak aralarında fark olmaksızın bütün azot dozlarından $(90.0,89.3,84.4$ ve 74.9 adet/bitki), en düşük ise üçüncü yılda uygulanan dördüncü azot dozundan (9.7 adet/bitki) alındığı tespit edilmiştir (Tablo 2). Deneme faktörleri arasında meydana gelen üçlü interaksiyonların toplam dal sayısına etkileri bakımından istatistiksel olarak önemli farklılıklara sahip olduğu gözlenmiş ve en yüksek toplam dal sayısının (104.3 adet/bitki) denemenin birinci yılında $0 \mathrm{~kg} / \mathrm{da}$ azot ve $2 \mathrm{~kg} \mathrm{da}^{-1}$ fosfor dozlarından alındığı saptanmıştır (Tablo 2).

\section{Bin Dane A ̆grırı̆̆}

Tablo 2'de görüldüğü gibi, yıllara ait iklim koşullarının bin dane ağırlığı üzerine istatistiksel olarak çok önemli (\%1) farklı etkilerinin olduğu ve en yüksek bin dane ağırlığı ortalama değerinin (6.4g) ikinci deneme yılından, en düşük (3.2g) ise üçüncü deneme yılından alındığı saptanmıştır. Bin dane ağırlığ aynı kalıtsal bir çeşit özelliği olmasına rağmen iriliği ve ağırlı̆̆ı sadece çeşide bağlı olmayıp iklim ve çevre şartlarından çok fazla etkilenmektedir. Özellikle, hasattan önce uzun bir kuraklık periyodunun neden olduğu eksik olgunluk, gelişme bozuklukları, kötü dane oluşumu düşük bin dane ağırlığına neden olmaktadır.

Denemede, farklı azot dozlarının bin dane ağırlığı üzerine olan etkileri bakımından istatistiki olarak önemli (\%5) farklılıkların meydana gelmediği ve azot dozlarına ait bin dane ağırlığı ortalama değerlerinin 5.0 - $5.2 \mathrm{~g}$ arasında değiştiği saptanmıştır. Çalışma sonuçlarının, denemelerinde artan azot dozlarının bin dane ağırlığı üzerinde önemli etkiye sahip olmadığını bildiren Erdoğdu ve Esendal (2018)'in bulgularıyla uyumlu olduğu tespit edilmiştir. Azot dozları arasında önemli bir fark olmamasının sebebi bitkilerin vejetasyon dönemlerinde çiçeklenme ve olgunlaşma aralığının kısa olması, bitkilerin bu evresinde ihtiyaç duydukları besin elementlerinin düşük olması olabilir (Kazemeini ve ark. 2010).

Farklı fosfor dozlarının bin dane ağırlığ üzerine olan etkilerinin istatistiki olarak önemli (\%5) olmadığı ve bin dane ağırlığı ortalama değerlerinin 5.0 ile $5.2 \mathrm{~g}$ arasında değiştiği saptanmıştır. Çalışma sonuçları fosforun kişnişte bin tohum ağırlı̆̆ı üzerine etkisinin olmadığını bildiren Sannappanavar (2019) ve Kan (2007)'nın sonuçları ile uyumlu olduğu tespit edilmiştir. 
Farklı Azot ve Fosfor Dozlarının Diyarbakır Ekolojik Koşullarında Kişniş (Coriandrum sativum var. microcarpum DC.) Bitkisinin Verim ve Bazı Verim Unsurları Üzerine Etkisi

Tablo 3. Kişnişte farklı azot ve fosfor dozları uygulamaları ile değişen tohum verimi, biyolojik verim ve hasat indeksi özelliklerine ilişkin üç yetiştirme sezonuna ait ortalama değerler, oluşturulan gruplar ve LSD değerleri

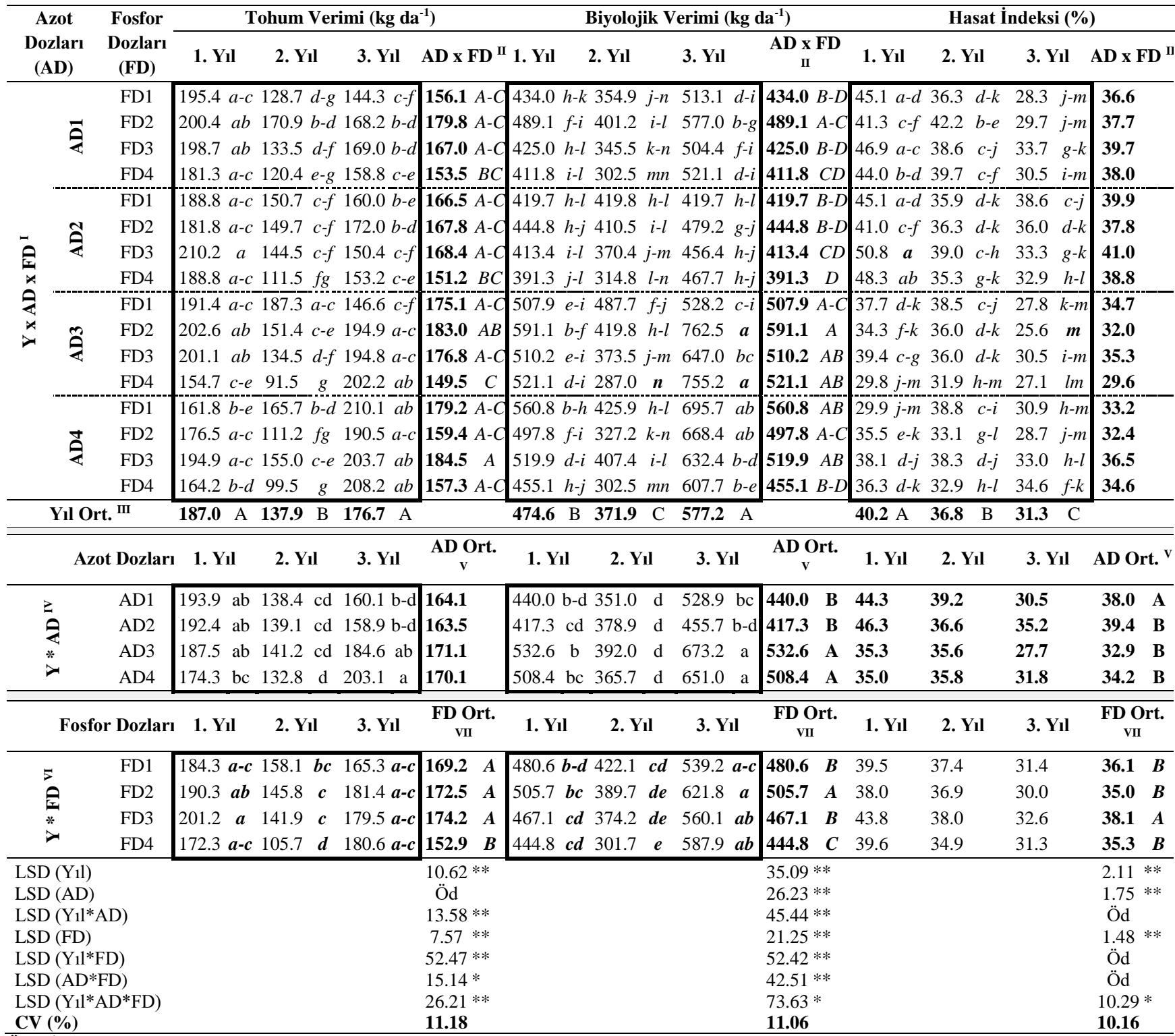

Öd : İstatistiksel olarak önemli değil (\%5)

* : Ortalamalar arasındaki farklılıklar \%5 düzeyinde önemli

** : Ortalamalar arasındaki farklılıklar \%1 düzeyinde önemli

I : Her bir özellik için aynı küçük italik harfler ile gösterilen ortalamalar arasında fark yoktur.

II : Her bir özellik için aynı sütunda aynı büyük italik harfler ile gösterilen ortalamalar arasında fark yoktur.

III : Her bir özellik için aynı satırda aynı büyük harfler ile gösterilen ortalamalar arasında fark yoktur.

IV : Her bir özellik için aynı küçük harfler ile gösterilen ortalamalar arasında fark yoktur.

V : Her bir özellik için aynı sütunda aynı büyük koyu harfler ile gösterilen ortalamalar arasında fark yoktur.

VI : Her bir özellik için aynı küçük italik koyu harfler ile gösterilen ortalamalar arasında fark yoktur.

VII : Her bir özellik için aynı sütunda aynı büyük italik koyu harfler ile gösterilen ortalamalar arasında fark yoktur.

\section{Tohum (meyve) Verimi (kg/da)}

Farklı azot ve fosfor dozları uygulamaları sonucunda elde edilen tohum verimi ortalama değerleri açısından yıllar arasında istatistiksel çok önemli (\%1) farklılıklar meydana gelmiş ve en yüksek tohum verimi ortalama değerlerinin 187.0 ve $176.7 \mathrm{~kg} \mathrm{da}^{-1}$ ile denemenin birinci ve üçüncü yıllarından, en düşük değerin ise denemenin ikinci yılında $137.9 \mathrm{~kg} \mathrm{da}^{-1}$ olarak alındığı saptanmıştır (Tablo 3).

Tablo 3 'ten de görüldüğü gibi, farklı azot dozu uygulamamaları sonucu dekara ortalama tohum verimlerinde meydana gelen farklılıkların istatistiki olarak önemli (\%5) olmadığı ve dekara tohum 
veriminin 163.5 ile $171.1 \mathrm{~kg}$ arasında değiştiği saptanmıştır. Azot, deneme toprakları gibi yüksek pH’lı yani bazik topraklarda amonyak haline dönüşerek büyük oranda kayba uğradığından etkinliği azalmaktadır. Bu nedenle, kontrole oranla artan azot dozuna bağlı bir artış olsa da tohum verimi üzerinde azotun dozlarının anlamlı olumlu bir etkiye sahip olmadığı saptanmıştır. Benzer konuda yapılan bazı çalışmalarda, artan azot dozuna bağlı olarak genelde tohum veriminde de bir artışın olduğunu bildirmişlerdir (Ali ve ark. 2015; Javiya ve ark. 2017; Moosavi ve ark. 2015), Erdoğdu ve Esendal (2018) ise azotun denemelerinde kullandıkları bütün çeşitlerde tohum verimi açısından aynı olumlu etkiyi göstermediğini rapor etmişlerdir.

Tablo 3 incelendiğinde, farklı fosfor dozu uygulamaları sonucu elde edilen tohum verimi ortalama değerleri arasında istatistiki olarak çok önemli (\%1) farklılıkların meydana geldiği ve en yüksek tohum verimlerinin ilk üç dozdan sırasıyla 169.2, 172.5 ve $174.2 \mathrm{~kg} \mathrm{da}^{-1}$, en düşük değerin ise dördüncü azot dozundan $152.9 \mathrm{~kg} \mathrm{da}^{-1}$ olarak alındığı tespit edilmiştir. Bu sonuçlara göre, artan fosfor dozlarına bağlı olarak tohum veriminin $4 \mathrm{~kg} \mathrm{P}_{2} \mathrm{O}_{5} \mathrm{da}^{-1}$ gübre dozuna kadar arttığı, bu dozdan sonra önemli düşüşlerin meydana geldiği görülmüştür (Tablo 3). Kişniş bitkisinde tohum verimi üzerine fosforun belli bir yarayışı doza kadar olumlu, artan ileri dozlarında ise önemli olumsuz etkilerinin olduğu Özyazici (2020) ve Javiya ve ark. (2017) tarafından da bildirilmiştir. Çalışmada elde edilen bulgulara benzer bir şekilde, Izgi (2020) yaptığ çalışma sonucunda fosfor dozlarının tohum verimi üzerinde istatistiksel olarak anlamlı olumlu bir etkisinin olmadığını vurgulamıştır.

Çalışmada, yıl x azot dozu (\%1), yıl x fosfor dozu (\%1), azot x fosfor dozu (\%5) ikili ve yıl x azot dozu x fosfor dozu (\%1) üçlü interaksiyonlarının istatistiki olarak önemli olduğu saptanmıştır. Buna göre yıl x azot dozu interaksiyonunda en yüksek tohum verimi $\left(203.1 \mathrm{~kg} \mathrm{da}^{-1}\right)$ üçüncü yılda dördüncü $(9 \mathrm{~kg}$ $\left.\mathrm{da}^{-1}\right)$ azot dozu uygulamasından, en düşük tohum verimi $\left(132.8 \mathrm{~kg} \mathrm{da}^{-1}\right)$ ise ikinci yılda dördüncü $(9 \mathrm{~kg}$ $\mathrm{da}^{-1}$ ) azot dozundan elde edilmiştir (Tablo 3). Y11 x fosfor dozu interaksiyonunda en yüksek tohum verimi (201.2 $\left.\mathrm{kg} \mathrm{da}^{-1}\right)$ birinci yılda üçüncü $\left(4 \mathrm{~kg} \mathrm{da}^{-1}\right)$ fosfor dozundan, en düşük tohum verimi (105.7 $\left.\mathrm{kg} \mathrm{da}^{-1}\right)$ ise ikinci yılda dördüncü $\left(6 \mathrm{~kg} \mathrm{da}^{-1}\right)$ fosfor dozundan elde edilmiştir. Azot $\mathrm{x}$ fosfor dozu interaksiyonunda en yüksek tohum verimi $\left(184.5 \mathrm{~kg} \mathrm{da}^{-1}\right)$ dördüncü $\left(9 \mathrm{~kg} \mathrm{da}^{-1}\right)$ azot ve dördüncü $(4 \mathrm{~kg}$ $\left.\mathrm{da}^{-1}\right)$ fosfor dozlarından, en düşük tohum verimi $\left(149.5 \mathrm{~kg} \mathrm{da}^{-1}\right)$ ise dördüncü $\left(9 \mathrm{~kg} \mathrm{da}^{-1}\right)$ azot ve dördüncü $\left(6 \mathrm{~kg} \mathrm{da}^{-1}\right)$ fosfor dozlarından elde edilmiştir. Faktörlerin üçlü (yıl x azot dozu x fosfor dozu) interaksiyonu sonucunda ise en yüksek tohum verimi $\left(210.2 \mathrm{~kg} \mathrm{da}^{-1}\right)$ birinci yılda, ikinci $\left(3 \mathrm{~kg} \mathrm{da}^{-1}\right)$ azot ve ikinci $\left(2 \mathrm{~kg} \mathrm{da}^{-1}\right)$ fosfor dozlarından, en düşük tohum verimi (91.5 ve $99.5 \mathrm{~kg} \mathrm{da}^{-1}$ ) ise ikinci yılda, üçüncü $\left(6 \mathrm{~kg} \mathrm{da}^{-1}\right)$ azot ve dördüncü $\left(6 \mathrm{~kg} \mathrm{da}^{-1}\right)$ fosfor dozu ile dördüncü $\left(9 \mathrm{~kg} \mathrm{da}^{-1}\right)$ azot ve dördüncü (6 $\mathrm{kg} \mathrm{da}^{-1}$ ) fosfor dozu interaksiyonlarından elde edilmiştir.

\section{Biyolojik Verim}

Tablo 3'te görüldüğü gibi, yıllara ait iklim koşullarının bin dane ağırlığı üzerine istatistiksel olarak çok önemli (\%1) farklı etkilerinin olduğu ve en yüksek biyolojik verim ortalama değerinin $\left(577.2 \mathrm{~kg} \mathrm{da}^{-}\right.$ $\left.{ }^{1}\right)$ üçüncü deneme yılından, en düşük $\left(371.9 \mathrm{~kg} \mathrm{da}^{-1}\right)$ ise ikinci deneme yılından alındığ saptanmıştır.

Denemede, farklı azot dozlarının biyolojik verim üzerine olan etkileri bakımından istatistiki olarak çok önemli (\%1) farklılıkların meydana geldiği ve azot dozlarına ait en yüksek biyolojik verim ortalama değerlerinin 532.6 ve $508.4 \mathrm{~kg} \mathrm{da}^{-1}$ ile üçüncü $\left(6 \mathrm{~kg} \mathrm{da}^{-1}\right)$ ve dördüncü $\left(9 \mathrm{~kg} \mathrm{da}^{-1}\right)$ azot dozlarından, en düşük değerlerin (440.0 ve $\left.417.3 \mathrm{~kg} \mathrm{da}^{-1}\right)$ ise birinci $\left(0 \mathrm{~kg} \mathrm{da}^{-1}\right)$ ve ikinci $\left(3 \mathrm{~kg} \mathrm{da}^{-1}\right)$ azot dozlardan alındığ 1 tespit edilmiştir. Azotun etkinliği üzerine yapılan çalışmalarda, Javiya ve ark. (2017) ve Kazemeini ve ark. (2010) artan azot dozu ile biyolojik verimin de arttığını belirtmiştir.

Farklı fosfor dozu uygulamaları sonucu elde edilen biyolojik verim ortalama değerleri arasında istatistiki olarak çok önemli (\%1) farklılıkların meydana geldiği ve en yüksek biyolojik verimin 505.7 
$\mathrm{kg} \mathrm{da}^{-1}$ ikinci fosfor dozundan $\left(2 \mathrm{~kg} \mathrm{da}^{-1}\right)$, en düşük değerin ise dördüncü fosfor dozundan $\left(6 \mathrm{~kg} \mathrm{da}^{-1}\right)$ $444.8 \mathrm{~kg} \mathrm{da}^{-1}$ olarak alındığ 1 tespit edilmiştir. Dekara $2 \mathrm{~kg}$ 'dan daha fazla uygulanan fosforun biyolojik verim üzerinde olumsuz etkilerinin olduğu gözlenmiştir. Çalışma sonuçlarının Javiya ve ark. (2017)'ın sonuçlarına benzer olduğu görülmüştür.

Tablo 3 incelendiğinde, y1l $\mathrm{x}$ azot dozu, y1l $\mathrm{x}$ fosfor dozu ve azot $\mathrm{x}$ fosfor dozu ikili interaksiyonlarının \%1 seviyesinde ve yıl x azot dozu $\mathrm{x}$ fosfor dozu üçlü interaksiyonunun ise $\% 5$ seviyesinde istatistiki olarak önemli olduğu saptanmıştır. Buna göre yıl x azot dozu interaksiyonu sonucunda en yüksek biyolojik verimlerinin (673.2 ve $651.0 \mathrm{~kg} \mathrm{da}^{-1}$ ) üçüncü yılda 6 ve $9 \mathrm{~kg} \mathrm{da}^{-1}$ azot dozu uygulamalarından, en düşük biyolojik verimlerinin $\left(351.0\right.$ - $\left.392.0 \mathrm{~kg} \mathrm{da}^{-1}\right)$ ise azot dozları arasında istatistiksel olarak herhangi bir farkın saptanmadığ i ikinci yılda dört azot dozu uygulamalarından elde edilmiştir (Tablo 3). Y1l x fosfor dozu interaksiyonunda en yüksek biyolojik verim $\left(621.8 \mathrm{~kg} \mathrm{da}^{-1}\right)$ üçüncü yılda ikinci $\left(2 \mathrm{~kg} \mathrm{da}^{-1}\right)$ fosfor dozu uygulamasından, en düşük biyolojik verim $\left(301.7 \mathrm{~kg} \mathrm{da}^{-1}\right)$ ise ikinci yılda dördüncü $\left(6 \mathrm{~kg} \mathrm{da}^{-1}\right)$ fosfor dozu uygulanmasından elde edilmiştir. Azot $\mathrm{x}$ fosfor dozu interaksiyonunda en yüksek biyolojik verim $\left(591.1 \mathrm{~kg} \mathrm{da}^{-1}\right)$ üçüncü $\left(6 \mathrm{~kg} \mathrm{da}^{-1}\right)$ azot ve ikinci $\left(2 \mathrm{~kg} \mathrm{da}^{-1}\right)$ fosfor dozlarından, en düşük biyolojik verim $\left(391.3 \mathrm{~kg} \mathrm{da}^{-1}\right)$ ise ikinci $\left(6 \mathrm{~kg} \mathrm{da}^{-1}\right)$ azot ve dördüncü (6 $\mathrm{kg} \mathrm{da}^{-1}$ ) fosfor dozu uygulamalarından elde edilmiştir. Faktörlerin üçlü (y1l x azot dozu x fosfor dozu) interaksiyonu sonucunda ise en yüksek biyolojik verim (762.5 ve $755.2 \mathrm{~kg} \mathrm{da}^{-1}$ ) üçüncü yılda, üçüncü (6 $\left.\mathrm{kg} \mathrm{da}^{-1}\right)$ azot ve ikinci $\left(2 \mathrm{~kg} \mathrm{da}^{-1}\right)$ fosfor dozu uygulamalarından, en düşük biyolojik verim (91.5 ve $\left.99.5 \mathrm{~kg} \mathrm{da}^{-1}\right)$ ise ikinci yılda, üçüncü $\left(6 \mathrm{~kg} \mathrm{da}^{-1}\right)$ azot ve dördüncü $\left(4 \mathrm{~kg} \mathrm{da}^{-1}\right)$ fosfor dozu uygulamalarından elde edilmiştir.

\section{Hasat İndeksi}

Farklı azot ve fosfor dozları uygulamaları sonucunda elde edilen hasat indeksi ortalama değerleri açısından yıllar arasında istatistiksel çok önemli (\%1) farklılıklar meydana gelmiş ve en yüksek hasat indeksi ortalama değerinin \% 40.2 ile denemenin birinci yılından, en düşük değerin ise denemenin üçüncü yılında 531.3 olarak alındığı saptanmıştır (Tablo 3).

Farklı azot dozu uygulamamaları sonucu hasat indeksi ortalama değerlerinde meydana gelen farklılıkların istatistiki olarak çok önemli (\%1) olduğu ve en yüksek hasat indeksi değerinin \%38.0 ile birinci $\left(0 \mathrm{~kg} \mathrm{da}^{-1}\right)$ azot dozundan, en düşük değerlerin (sırasıyla, \% 39.4, 32.9 ve 34.2) ise aralarında istatistiksel olarak fark olmayan diğer üç azot dozlarından elde edildiği saptanmıştır. Deneme sonuçlarının, kontrole oranla hasat indeksinin dekara $6 \mathrm{~kg}$ azot uygulamasına kadar arttığını ve sonraki dozlarda ise düşmeye başladığını rapor eden Erdoğdu ve Esendal (2018)'ın bulgularına kısmen benzerlik gösterdiği görülmüştür.

Farklı fosfor dozu uygulamaları sonucu elde edilen hasat indeksi ortalama değerleri arasında istatistiki olarak çok önemli (\%1) farklılıkların meydana geldiği ve en yüksek hasat indeksi ortalama değerinin \%38.1 üçüncü fosfor dozundan $\left(4 \mathrm{~kg} \mathrm{da}^{-1}\right)$, en düşük değerlerin (sırasıyla, \% 36.1, 35.0 ve 35.3) ise aralarında istatistiki olarak fark bulunmayan diğer üç azot dozlarından elde edildiği saptanmıştır. Çalışma sonuçlarının Javiya ve ark. (2017)'ın sonuçlarına kısmen benzer olduğu görülmüştür.

Faktörlerin üçlü (yıl x azot dozu x fosfor dozu) interaksiyonu sonucunda ise en yüksek hasat indeksi (\%50.8) üçüncü yılda, ikinci $\left(3 \mathrm{~kg} \mathrm{da}^{-1}\right)$ azot ve üçüncü $\left(4 \mathrm{~kg} \mathrm{da}^{-1}\right)$ fosfor dozu uygulamalarından, en düşük hasat indeksi değerinin (\%25.6) ise üçüncü yılda, üçüncü $\left(6 \mathrm{~kg} \mathrm{da}^{-1}\right)$ azot ve ikinci $\left(2 \mathrm{~kg} \mathrm{da}^{-1}\right)$ fosfor dozu uygulamalarından elde edilmiştir. 


\section{İncelenen Özellikler Arası İlişkiler}

Tablo 4. Kişnişte bitki boyu, toplam dal sayısı, bin dane ağırlığı, tohum verimi, biyolojik verim ve hasat indeksi özelliklerine ilişkin korelasyon kat sayıları ve önemlilik dereceleri

\begin{tabular}{|c|c|c|c|c|c|c|c|c|c|c|}
\hline Özellikler & BB & TDS & BDA & & TV & & BV & & HI & \\
\hline Bitki boyu (BB) & 1 & 0.012 & -0.649 & ** & 0.656 & $* *$ & 0.644 & ** & -0.109 & \\
\hline Toplam dal sayısı (TDS) & & 1 & 0.695 & $* *$ & 0.161 & & -0.368 & $*$ & 0.671 & $* *$ \\
\hline Bin dane ağırlığ 1 (BDA) & & & 1 & & -0.310 & * & -0.664 & ** & 0.522 & $* *$ \\
\hline Tohum verimi (TV) & & & & & 1 & & 0.691 & $* *$ & 0.230 & \\
\hline Biyolojik verim (BV) & & & & & & & 1 & & -0.530 & $* *$ \\
\hline Hasat indeksi (HI) & & & & & & & & & 1 & \\
\hline
\end{tabular}

*: Korelasyon $\% 5$ düzeyinde önemlidir.

**: Korelasyon $\% 1$ düzeyinde önemlidir.

Tablo 4'te görüldüğ̈̈ bitki boyunun bin dane ağırlığı ile negatif ve çok önemli ( $\mathrm{r}=-0.649 * *)$, tohum verimi ile pozitif ve çok önemli $\left(\mathrm{r}=0.656^{* *}\right)$ ve biyolojik verim ile pozitif ve çok önemli $\left(\mathrm{r}=0.644^{* *}\right)$ bir ilişki saptanmıştır. Aynı şekilde toplam dal sayısı ile bin dane ağırlığı arasında pozitif ve çok önemli $\left(\mathrm{r}=0.695^{* *}\right)$, biyolojik verim ile negatif ve önemli $(\mathrm{r}=-0.368)$, hasat indeksi ile pozitif ve çok önemli $(\mathrm{r}=$ $\left.0.671^{* *}\right)$ bir ilişki saptanmıştır. Bin dane ağırlığı ile tohum verimi arasında negatif ve önemli ( $\mathrm{r}=-$ $\left.0.310^{*}\right)$, biyolojik verim ile negatif ve çok önemli $\left(\mathrm{r}=-0.664^{* *}\right)$ ve hasat indeksi ile pozitif ve çok önemli bir ilişki saptanmıştır. Tohum verimi ile biyolojik verim arasında pozitif ve çok önemli $\left(r=0.691^{* *}\right)$ bir ilişki saptanmıştır. Biyolojik verim ile hasat indeksi arasında negatif ve çok önemli $(r=-0.530 * *)$ bir ilişki saptanmıştır. Özellikler arasındaki ilişkilere dair pozitif ve negatif sonuçlar, Özel ve ark. (2009)'larının bulgularıyla kısmen örtüşmektedir. Bunun nedeninin genetik yapı, çevresel koşullar ve uygulanan yetiştirme tekniklerinden kaynaklandığı düşünülmektedir.

\section{SONUÇ}

Diyarbakır koşullarında yetiştirilebilecek kişniş bitkisinde farklı azot ve fosfor dozlarının kişnişin verim ve bazı verim unsurları üzerine olan etkilerini incelemek amacıyla yürütülen üç yıllık çalışma sonucunda; azotun tohum verimi üzerine anlamlı bir etkisi olmazken, kontrole oranla artan fosfor dozlarının verimi düşürdüğü gözlenmiş, fakat en yüksek tohum veriminin $\left(184.5 \mathrm{~kg} \mathrm{da}^{-1}\right)$ her iki gübrenin etkileşimi sonucunda ( $9 \mathrm{~kg} \mathrm{da}^{-1}$ azot ve $4 \mathrm{~kg} \mathrm{da}^{-1}$ fosfor) alındığı saptanmıştır. Çalışmada elde edilen bulgular 1şığında kişniş bitkisinin azot ve fosforlu gübre ihtiyacının çok fazla olmadığı, eğer azot ve fosfor uygulaması yapılacaksa topraktaki mevcut yarayışlı N ve P içeriğine göre ilave gübrelemenin kombinasyon halinde yapılmasının uygun olacağı söylenebilir.

\section{Çıkar Çatışması}

Makale yazarları aralarında herhangi bir çıkar çatışması olmadığını beyan ederler.

\section{Yazar Katkısı}

Yazarlar makaleye eşit oranda katkı sağlamıştır.

\section{KAYNAKÇA}

Ali H, Ayub G, Elahi E, Shahab M, Ahmed S, Ahmed N, 2015. Response of coriander (Coriandrum sativum L.) to different nitrogen levels and sowing dates. Asian Journal of Agriculture and Biology, 3 (4): 155 158.

Baydar H, 2005. Tibbi ve aromatik ve keyf bitkileri bilimi ve teknolojisi. Süleyman Demirel Üniversitesi Ziraat Fakültesi SDÜ Yayınları. Yayın No: 51. s: 154, Isparta.

Beyzi E, Gürbüz B, 2010. Ülkemizde kişniş Coriandrum sativum L. üretimi ve bitkinin genel özellikleri. Ziraat Mühendisliği, 354: 24-27. 
Davis PH, 1984. Flora of Turkey and East Aegean İsland. Vol: 4, Edinburg University Pres. Died erichsen, A., 1966. result of characterization of germplasm collection of coriander (Coriandrum sativum L.) in the Gatersleben Genebank. Inter. Symp. Breeding Res. On Med. And Aromatik Plants, June 30-July 4. Quedlinburg Germany. 45-48.

Diederichsen A, 1996. Coriander (Coriandrum sativum L.). ISBN 92-9043-284-5. P:1-83.

Erdoğdu Y, Esendal E, 2018. The effects of nitrogen doses on the seed yield and some agronomic characteristics of coriander cultivars. Journal of Tekirdag Agricultural Faculty, 15 (1).

Izgi M, 2020. The Effect of Different phosphorus doses on agronomic and quality characteristics of coriander (Coriandrum Sativum L.). Applied Ecology and Environmental Research, 18 (6): 8205-8216.

Javiya P, Solanki J, Kaneria S, Rupareliya V, 2017. Response of Coriander (Coriandrum sativum L.) to Nitrogen and Phosphorus in South Saurashtra Condition. International Journal of Pure \& Applied Bioscience, 5 (4): 860-866.

Kan Y, 2007. Konya ekolojik koşullarında yetiştirilen kişniş (Coriandrum sativum L.)'de uygulanan organik ve inorganik gübrelerin verim ve uçucu yağ oranı üzerine etkileri. Selçuk Tarım ve Gıda Bilimleri Dergisi, 21 (42): 36-42.

Kaya N, Yılmaz G, Telci İ, 2000. Farklı zamanlarda ekilen kişniş (Coriandrum sativum L.) populasyonlarının agronomik ve teknolojik özellikleri. Turkish Journal of Agriculture and Forestry, 24: 355-364.

Kazemeini SA, Hamzehzarghani H, Edalat M, 2010. The impact of nitrogen and organic matter on winter canola seed yield and yield components. Australian Journal of Crop Science, 4 (5): 335.

Kırıcı S, Mert A, Ayanoğlu F, 1997. Hatay ekolojisinde azot ve fosfor'un kişniş (Coriandrum sativum)'de verim değerleri ile uçucu yă̆ oranlarına etkisi. Türkiye II. Tarla Bitkileri Kongresi, 22-25 Eylül, Samsun. Bildiriler Kitabı. S: 347-351.

Moosavi G, Seghatoleslami M, Ebrahimi A, Fazeli M, Jouyban Z, 2015. The effect of nitrogen rate and plant density on morphological traits and essential oil yield of coriander. Journal of Ornamental Plants, 3 (2): 95-103.

Özel A, Güler İ, Erden K, 2009. Harran Ovası koşullarında farklı ekim zamanlarının kişniş (Coriandrum sativum L.)'in verim ve bazı bitkisel özelliklerine etkisi. Harran Üniversitesi Ziraat Fakültesi Dergisi, 13 (4): 41-48.

Özyazici G, (2020). Farklı fosfor dozlarının kişniş (Coriandrum sativum L.) bitkisinde verim ve bazı tarımsal özelliklere etkisi. Türkiye Tarımsal Araştırmalar Dergisi, 7 (2): 192-200.

Sannappanavar S, 2019. Performance of coriander (Coriandrum Sativum L.) to different sources of organic phosphorus and psb on growth, seed yield. International Journal of Current Microbiology and Applied Sciences, 8 (8): 2584-89.

Saya Ö, Ertekin S, Çetin H, Hoigören H, Toker Z, Aksal M, 2001. GAP yöresindeki endemik ve tıbbi bitkiler. Sayfa No: 66-67. Türkiye Çevre vakfi, Tunalı Hilmi cad. 50/2 06660 Kavaklıdere Ankara.

Tunçtürk M, Sciences F, 2006. Kişniş (Coriandrum sativum L.) bitkisinde farklı tohumluk miktarlarının verim, verim özellikleri ve uçucu yağ oranı üzerine etkisi. Selcuk Journal of Agriculture, 20 (39): 5862.

Tunçtürk R, 2011. Kişniş (Coriandrum sativum L.) çeşitlerinde değişik ekim mesafelerinin verim ve kalite üzerine etkisi. Yüzüncü Yıl Üniversitesi Tarım Bilimleri Dergisi, 21 (2): 89-97.

Tunçtürk R, Tunçtürk M, 2008. Farklı azot dozu uygulamalarının bazı kişniş popülasyonlarında verim ve verim özellikleri üzerine etkisi. Yüzüncü Y1l Üniversitesi Fen Bilimleri Enstitüsü Dergisi, 13 (1): 39 44. 